\title{
ONE-DIMENSIONAL FLAME INSTABILITY AND CONTROL OF BURNING IN FIRE-CHAMBER
}

Introduction. Multidimensional flame instability (two-dimensional instability as its special case) is well investigated analytically $[1,2]$. Such kind of instability leads to distortion of the flame front $[1,2]$ and causes cellular structure of flame and turbulent combustion [3]. Multidimensional flame instability can be also the reason of deflagration-to-detonation transition (DDT) [4].

But there are not many theoretical investigations of flame stability for one-dimensional case. This fact is entirely understandable since realization of one-dimensional instability is impossible under development of multidimensional perturbations in case of the instable flame front. Still the case of onedimensional flame instability is rather important from practical point of view for situations when multidimensional perturbations can't develop because of boundary conditions (for example the wave length $\lambda_{m}$ that corresponds to the perturbation with the fastest growth rate of amplitude is more than the tube diameter or the channel width).

One-dimensional flame instability can be the reason of vibratory combustion in fire-chambers [5]. This regime causes rapid variation of pressure and velocity in space and time. The increased pressure perturbations wreck the walls of chamber and can destroy it completely. By the way powerful longitudinal pulsations can ruin the process of burning. Since there is problem of the fire-chamber control to prevent flame from intensive oscillations and vibrations.

Literature review. On the one hand vibratory combustion [5] is rather well studied by L. Crocco, S.-I. Cheng, B. Raushenbach, M. Natanson. Proceedings of V.V. Gotsulenko [6, 7] contain modern interesting ideas and thoughts of the flame oscillations and their control. But on the other hand the problem of the vibratory combustion development is still unsolved. There are no fully clear theoretical explanations (neither mathematical nor mechanical and physical) for longitudinal pulsations of pressure and velocity in the direction of the tube axis or channel axis. This work is only an attempt (may be primitive enough) to explain the origin of such perturbations at least mathematically, from the point of view of gas dynamics, without analyzing any physical and chemical reasons.

Aim of the Research is to investigate one-dimensional stability of flames in closed tubes, channels and chambers; to ground mathematically the control of burning in fire-chambers.

Main Body.

Mathematical model. The following mathematical model of combustion is considered (Fig. 1). Along $x$-axis, at $x<0$, the ideal inviscid gas moves at a stationary subsonic velocity $u_{1}\left(u_{1}\right.$ is much less than the sonic speed $a_{1}$; velocity $u_{1}$ equals the burning rate or the fuel supply rate). Plane $x=0$ corresponds to the flame front. Planes $x=-L_{1}$ and $x=L_{2}$ correspond to front and back hard walls accordingly (these walls can be regarded as the fire-chamber walls or as the closed ends of tube or channel). Zone "1" $\left(-L_{1}<x<0\right)$ is occupied by combustible gas mixture, whereas zone "2" $\left(0<x<L_{2}\right)$ is occupied by the combustion products. The combustion products are the ideal homogeneous inviscid gas moving at a stationary subsonic velocity $u_{2}$ ( $u_{2}$ is also much less than the sonic speed $a_{2}$ in products). It is obvious that $L=L_{1}+L_{2}$, where $\mathrm{L}$ is the total chamber length. It is assumed that all physical and chemical transformations occur in a moment on the flame front $x=0$. This assumption is correct if the width of the flame zone is much less than the total chamber length $L$. It is not necessarily to mean by the flame only laminar flame with plane front because of the small physical width of this kind of flame

DOI 10.15276/opu.1.45.2015.14

(C) V.E. Volkov, 2015

ЕНЕРГЕТИКА. ТЕПЛОТЕХНІКА. ЕЛЕКТРОТЕХНІКА 


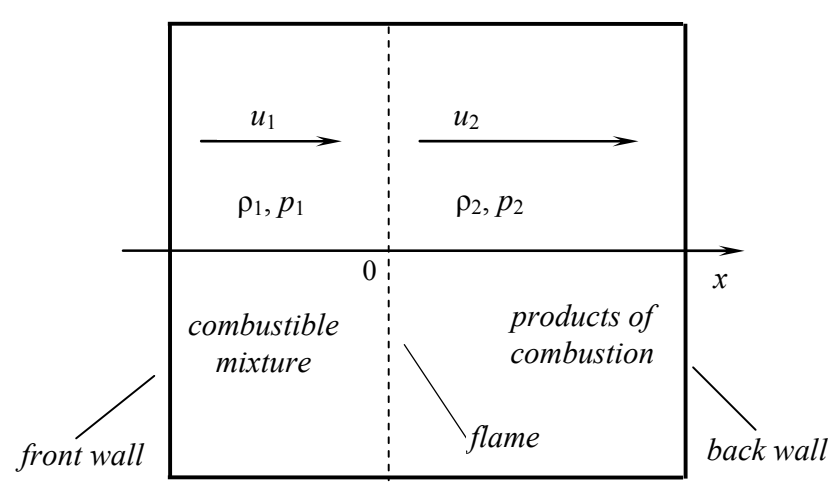

Fig. 1. Scheme of flame in closed fire-chamber, tube or channel

$(0,1 \ldots 10 \mathrm{~mm})$. It may be also laminar flame with slightly distorted front but with effective width (including its distortion) much less than $L$. The turbulent flame also satisfies this model if its fire zone with fuzzy front (which is by a lot of physical reasons much wider than the laminar flame zone) is much more narrow than the chamber extent $L$.

This model is fit either for the combustion in fire-chamber or for the flame propagating in tube or channel (with the frame of reference connected to the flame front). In the last case the ends of tube or channel must also move in the frame of reference connected to the flame, but this movement is negligible regarding to comparison of the low velocity $u_{1}$ with velocities of acoustic perturbations mentioned below.

The parameters of combustible and products of combustion are related to each other by the conservation laws of mass, momentum and energy

$$
\left\{\begin{array}{l}
\rho_{1} u_{1}=\rho_{2} u_{2}=\frac{u_{1}}{v_{1}}=\frac{u_{2}}{v_{2}} \\
p_{1}+\rho_{1} u_{1}^{2}=p_{2}+\rho_{2} u_{2}^{2}=p_{1}+\frac{u_{1}^{2}}{v_{1}}=p_{2}+\frac{u_{2}^{2}}{v_{2}} \\
h_{1}+q+\frac{u_{1}^{2}}{2}=h_{2}+\frac{u_{2}^{2}}{2}
\end{array}\right.
$$

where $\rho_{j}$ is density;

$v_{j}$ is specific volume $\left(v_{j}=\frac{1}{\rho_{j}}\right)$;

$p_{j}$ is pressure;

$q$ is the chemical energy discharge per unit mass of gas;

$h_{j}=h_{j}\left(p_{j}, \rho_{j}\right)=h_{j}\left(p_{j}, v_{j}\right)$ is specific enthalpy;

$j=1,2$.

For the thermally perfect gas

$$
h_{j}=\frac{\gamma_{j} p_{j}}{\left(\gamma_{j}-1\right) \rho_{j}}=\frac{\gamma_{j} p_{j} v_{j}}{\gamma_{j}-1},
$$

where $\gamma_{j}$ is the ratio of specific heats.

Fundamental equations and their linearization. The flow field is governed by a set of onedimensional gasdynamic equations

$$
\left\{\begin{array}{l}
\frac{\partial u}{\partial t}+u \frac{\partial u}{\partial x}+\frac{1}{\rho} \frac{\partial p}{\partial x}=0 \\
\frac{\partial \rho}{\partial t}+u \frac{\partial \rho}{\partial x}+\rho \frac{\partial u}{\partial x}=0 \\
\frac{\partial p}{\partial t}+u \frac{\partial p}{\partial x}+\gamma p \frac{\partial u}{\partial x}=0
\end{array}\right.
$$

where $t$ is time. 
More convenient form of standard equations (1) is

$$
\left\{\begin{array}{l}
\frac{\partial u}{\partial t}+u \frac{\partial u}{\partial x}+v \frac{\partial p}{\partial x}=0 \\
\frac{\partial v}{\partial t}+u \frac{\partial v}{\partial x}-v \frac{\partial u}{\partial x}=0 \\
\frac{\partial p}{\partial t}+u \frac{\partial p}{\partial x}+\gamma p \frac{\partial u}{\partial x}=0
\end{array}\right.
$$

Let us consider that the flame front obtains small (infinitesimal) displacement $\varepsilon(t)=A_{00} L \exp (-i \omega t)$ as a result of accidental processes inside the flame zone. So equation of the disturbed flame front is

$$
x=\varepsilon(t)=A_{00} L \exp (-i \omega t),
$$

where $i$ is unit imaginary number $\left(i^{2}=-1\right)$;

$A_{00}$ is indefinite constant;

$\omega$ is complex number (main component of eigen-value).

Such a choice for the form of perturbations is connected with possibility to present (by time coordinate $t$ ) every linearized perturbation as a Fourier series or a Fourier integral that is to get this perturbation as superposition of the elementary waves of the exponential type $\exp (-i \omega t)$.

Stationary flows of combustible gas (in zone "1") and products of combustion (in zone "2") are also disturbed, that is

$$
u=u_{j}+u_{j}^{\prime}(x, t), p=p_{j}+p_{j}^{\prime}(x, t), v=v_{j}+v_{j}^{\prime}(x, t),
$$

where $u_{j}^{\prime}(x, t), p_{j}^{\prime}(x, t), v_{j}^{\prime}(x, t)$ are small (infinitesimal) perturbations of velocity, pressure and specific volume accordingly.

Let us substitute expressions (4) into equations (2) and neglect all infinitesimals of second infinitesimal order (that is the essence of linearization). Set of linearized equations is

$$
\left\{\begin{array}{c}
\frac{\partial u_{j}^{\prime}}{\partial t}+u_{j} \frac{\partial u_{j}^{\prime}}{\partial x}+v_{j} \frac{\partial p_{j}^{\prime}}{\partial x}=0 \\
\frac{\partial v_{j}^{\prime}}{\partial t}+u_{j} \frac{\partial v_{j}^{\prime}}{\partial x}-v_{j} \frac{\partial u_{j}^{\prime}}{\partial x}=0 \\
\frac{\partial p_{j}^{\prime}}{\partial t}+u_{j} \frac{\partial p_{j}^{\prime}}{\partial x}+\gamma_{j} p_{j} \frac{\partial u_{j}^{\prime}}{\partial x}=0
\end{array}\right.
$$

Particular solutions of equations (5) are

$$
\left\{\begin{array}{l}
\frac{v_{1} p_{j}^{\prime}}{u_{1}^{2}}=\sum_{l=1}^{2} A_{j l} \exp \left(k_{j l} \frac{x}{L}-i \omega t\right) ; \\
\frac{u_{j}^{\prime}}{u_{1}}=M_{j} \sum_{l=1}^{2} A_{j l}(-1)^{l} \exp \left(k_{j l} \frac{x}{L}-i \omega t\right) ; \\
\frac{v_{j}^{\prime}}{v_{1}}=\left[-M_{j}^{2} \sum_{l=1}^{2} A_{j l} \exp \left(k_{j l} \frac{x}{L}\right)+A_{j 3} \exp \left(k_{j 3} \frac{x}{L}\right)\right] \exp (-i \omega t),
\end{array},\right.
$$

where $k_{j 1}=\frac{z M_{j}}{\delta_{j}\left(1-M_{j}\right)}, k_{j 2}=-\frac{z M_{j}}{\delta_{j}\left(1+M_{j}\right)}, k_{j 3}=-\frac{z}{\delta_{j}}$;

$$
\begin{aligned}
& \delta_{j}=\frac{\rho_{1}}{\rho_{j}}=\frac{u_{j}}{u_{1}}=\frac{v_{j}}{v_{1}}\left(\delta_{1}=1\right) ; \\
& z=-\frac{i \omega L}{u_{1}} ;
\end{aligned}
$$




\section{$A_{j l}$ are indefinite constants.}

There are three kinds of perturbations both in zone "1" (combustible gas) and zone "2" (products of combustion). Perturbations of the first kind (corresponding to $A_{j 1}, k_{j 1}$ ) and of the second kind (corresponding to $A_{j 2}, k_{j 2}$ ) are plane acoustic waves. Perturbations of the third kind (corresponding to $A_{j 3}, k_{j 3}$ ) are perturbations of specific volume only. These perturbations are caused by perturbations of entropy. It is quite correct to suppose that there are no perturbations of the third kind in zone " 1 " because these perturbations are carried by the main (stationary) stream, and the flame front is supposed the only source of perturbations for the problem of flame internal stability. This supposition leads to condition $A_{13}=0$.

Boundary conditions. Boundary conditions at the flame front are laws of conservation of mass, momentum and energy for the disturbed flow. In the linear approximation these laws are given by

$$
\begin{gathered}
\left.\left(\frac{u_{1}^{\prime}}{u_{1}}-\frac{v_{1}^{\prime}}{v_{1}}-\frac{1}{\delta_{2}} \frac{u_{2}^{\prime}}{u_{1}}+\frac{1}{\delta_{2}} \frac{v_{2}^{\prime}}{v_{2}}\right)\right|_{x=x_{0}}+\left(\frac{1}{\delta_{2}}-1\right) \frac{1}{u_{1}} \frac{d \varepsilon}{d t}=0, \\
\left.\left(\frac{v_{1} p_{1}^{\prime}}{u_{1}^{2}}+2 \frac{u_{1}^{\prime}}{u_{1}}-\frac{v_{1}^{\prime}}{v_{1}}-\frac{v_{1} p_{2}^{\prime}}{u_{1}^{2}}-2 \frac{u_{2}^{\prime}}{u_{1}}+\frac{v_{2}^{\prime}}{v_{1}}\right)\right|_{x=x_{0}}=0, \\
\left.\left(\frac{\gamma_{1}}{\gamma_{1}-1} \frac{v_{1} p_{1}^{\prime}}{u_{1}^{2}}+\frac{1}{\left(\gamma_{1}-1\right) M_{1}^{2}} \frac{v_{1}^{\prime}}{v_{1}}+\frac{u_{1}^{\prime}}{u_{1}}-\frac{\delta_{2} \gamma_{2}}{\gamma_{2}-1} \frac{v_{1} p_{2}^{\prime}}{u_{1}^{2}}-\frac{\delta_{2}}{\left(\gamma_{2}-1\right) M_{2}^{2}} \frac{v_{2}^{\prime}}{v_{1}}-\delta_{2} \frac{u_{2}^{\prime}}{u_{1}}\right)\right|_{x=x_{0}}+ \\
+\left(\frac{1}{\gamma_{1} M_{1}^{2}}-\frac{\delta_{2}}{\gamma_{2} M_{2}^{2}}\right) \frac{1}{u_{1}} \frac{d \varepsilon}{d t}=0,
\end{gathered}
$$

where $M_{j}=\frac{u_{i}}{a_{j}}$ is Mach number.

The additional boundary condition at the flame front is well-known condition of Landau

$$
\left.\frac{u_{1}^{\prime}}{u_{1}}\right|_{x=x_{0}}-\frac{1}{u_{1}} \frac{d \varepsilon}{d t}=0 .
$$

Boundary conditions on the hard walls are

$$
\begin{aligned}
& \left.\frac{u_{1}^{\prime}}{u_{1}}\right|_{x=-L_{1}}=0, \\
& \left.\frac{u_{2}^{\prime}}{u_{1}}\right|_{x=L_{2}}=0 .
\end{aligned}
$$

Eigen-value problem. Substitution of particular solutions (6) into boundary conditions (7)...(12) leads to the set of six linear algebraic homogeneous equations for six indefinite constants $A_{00}, A_{11}, A_{12}, A_{21}, A_{22}, A_{23}$. This set of equations has untrivial solution if and only if its determinant equals zero. And so this is the eigen-value problem for $z$, that leads to characteristic (secular) equation

$$
z\left\{A \exp \left[\left(\alpha_{1}+\alpha_{2}\right) z\right]+B \exp \left(\alpha_{1} z\right)+C \exp \left(\alpha_{2} z\right)+D\right\}=0,
$$

where $\quad \alpha_{1}=\frac{2 M_{1}}{1-M_{1}^{2}} \frac{L_{1}}{L}, \quad \alpha_{2}=\frac{2 M_{2}}{\delta_{2}\left(1-M_{1}^{2}\right)} \frac{L_{2}}{L}$,

$A, B, C, D$ are cumbersome constant coefficients depending on $\gamma_{1}, \gamma_{2}, M_{1}, M_{2}, \delta_{2}$. 
It is obvious that equation (13) has neutral root $z=0$ (this root is physically senseless). Therefore the problem is to solve

$$
A \exp \left[\left(\alpha_{1}+\alpha_{2}\right) z\right]+B \exp \left(\alpha_{1} z\right)+C \exp \left(\alpha_{2} z\right)+D=0 .
$$

For solving of the stability problem it is enough to know only signs of roots for the equation (14). If equation (14) has a root with positive real part (that is $\operatorname{Re} z>0$ ) then instability takes place. If all the roots of equation (14) have a negative real part (that is $\operatorname{Re} z<0$ ) then the process is stable to perturbations of the exponential type (3). But this fact is not a guarantee of the absolute stability for the flow and the flame front.

Function in the left part of the equation (14) is primitive quasipolynomial with the main part (for $z$ ). It is known that such quasipolynomial may be stable or unstable in general. In this concrete case both situations are also possible (it depends on values of parameters $\gamma_{1}, \gamma_{2}, M_{1}, M_{2}, \delta_{2}, L_{1} / L$ and $L_{2} / L$ (but $\left.L_{1} / L+L_{2} / L=1\right)$ ).

Results. It is known that the combustible gas density is much more than the density of products, that is

$$
\delta_{2}=\frac{\rho_{1}}{\rho_{2}}=\frac{u_{2}}{u_{1}}=\frac{v_{2}}{v_{1}}>1 .
$$

Such inequalities also take place:

$$
\begin{aligned}
& \gamma_{1}<1, \gamma_{2}<1, \\
& M_{1}<M_{2}<1 .
\end{aligned}
$$

It is also necessary to notice that $\gamma_{1}<\gamma_{2}$ as usual, and Mach numbers are much less than 1 for the normal combustion of the overwhelming majority of gas mixtures.

Let us consider two extreme cases with regard to inequalities (15)...(17).

First extreme case is

$$
\frac{L_{1}}{L} \rightarrow 1, \quad \frac{L_{2}}{L} \rightarrow 0,
$$

and as a result

$$
\alpha_{1} \rightarrow \frac{2 M_{1}}{1-M_{1}^{2}}, \quad \alpha_{2} \rightarrow 0
$$

In this case

$$
\begin{gathered}
\exp \left(\alpha_{1} z\right)=-\frac{C+D}{A+B}, \\
\operatorname{Re} z=\frac{1}{\alpha_{1}} \ln \left(\left|\frac{C+D}{A+B}\right|\right) .
\end{gathered}
$$

It follows $\operatorname{Re} z<0$ and stability takes place.

Second extreme case is

$$
\frac{L_{1}}{L} \rightarrow 0, \quad \frac{L_{2}}{L} \rightarrow 1
$$

and as a result

$$
\alpha_{1} \rightarrow 0, \alpha_{2} \rightarrow \frac{2 M_{2}}{\delta_{2}\left(1-M_{2}^{2}\right)}
$$

In this case 


$$
\begin{gathered}
\exp \left(\alpha_{2} z\right)=-\frac{B+D}{A+C}, \\
\operatorname{Re} z=\frac{1}{\alpha_{2}} \ln \left(\left|\frac{B+D}{A+C}\right|\right) .
\end{gathered}
$$

It follows $\operatorname{Re} z>0$ and instability takes place.

Therefore the flame front is stable (with respect to one-dimensional exponential perturbations) near the back wall of chamber or near the end of tube (channel) from which the flame is propagating. On the contrary it is unstable near the front wall of chamber or near the end of tube (channel) towards which the flame is propagating.

In both cases theoretical conclusions are in good agreement with experimental data (for example the flame propagating in a narrow tube begins to "sing" as it approaches its end as a result of onedimensional instability $[6,7])$. This fact proves correctness of the suggested theory.

\section{Conclusions:}

- One-dimensional instability of the flame front in the fire-chamber mathematically explains the nature of vibratory combustion. This regime of combustion is caused by the development of the longitudinal perturbations (pulsations) of pressure and velocity which are the consequence of onedimensional instability. This regime causes also loud noises in engines.

- One-dimensional instability develops in time for flames propagating in narrow tubes or channels (tube must be narrow enough to prevent the development of multidimensional instability).

- Combustion in engines needs control to avoid vibratory combustion or (if the vibratory combustion regime is inevitable) to diminish pulsations as much as possible. The aim of this control is to support burning of combustible gas mixture in the flame front situated at the maximum possible distance from the front wall of the fire-chamber (from which the fuel supply is realized). Possibilities and methods of such control differs greatly for various engines and fire-chambers. Such possibilities and methods exceed the limits of the present investigation.

\section{Література}

1. Aslanov, S.K. Instability and Structure of Detonation in a Model Combustor / S.K. Aslanov, V.E. Volkov // Application of Detonation to Propulsion / [ed. by G.D. Roy, S.M. Frolov, J.E. Shepherd]. — Moscow: TORUS PRESS Ltd., 2004. — PP. 17 - 25.

2. Volkov, V.E. Instability of Flames in Cylindrical Tubes and Combustors / V.E. Volkov // Third International Symposium on Nonequilibrium Processes, Combustion, Plasma, and Atmospheric Phenomena, Sochi, Russia, June 25-29, 2007. — Moscow: TORUS PRESS Ltd., 2007. - P. 46.

3. Volkov, V.E. Mathematical simulation of laminar-turbulent transition and the turbulence scale estimation / V.E. Volkov // Пр. Одес. політехн. ун-ту. — 2014. — Вип. 2(44). - С. 155 - 159.

4. Volkov, V.E. Deflagration-to-detonation transition and the detonation induction distance estimation / V.E. Volkov // Пр. Одес. політехн. ун-ту. — 2014. — Вип. 1(43). — С. $120-126$.

5. Gotsulenko, V.V. On the problem of control of relaxation oscillations of a "singing" flame / V.V. Gotsulenko // Journal of Engineering Physics and Thermophysics. — 2007. — Vol. 80, Issue 3. PP. $563-569$.

6. Gotsulenko, V.V. Distinctive features of the intrachamber instability of combustion in liquid-propellant rocket engines / V.V. Gotsulenko // Journal of Engineering Physics and Thermophysics. - 2008. Vol. 81, Issue 5. - PP. 935 - 940.

7. Liberman, M.A. Introduction to Physics and Chemistry of Combustion / M.A. Liberman. - Berlin, Heidelberg: Springer-Verlag., 2008. -365 p.

\section{References}

1. Aslanov, S.K. and Volkov, V.E. (2004). Instability and structure of detonation in a model combustor. In G.D. Roy, S.M. Frolov, J.E. Shepherd (Eds.), Application of Detonation to Propulsion (pp. 17-25). Moscow: TORUS PRESS Ltd. 
2. Volkov, V.E. (2007). Instability of flames in cylindrical tubes and combustors. In G.D. Roy, S.M. Frolov and A.M. Starik (Eds.), Proceedings of Third International Symposium on Nonequilibrium Processes, Combustion, Plasma, and Atmospheric Phenomena (p. 46). Moscow: TORUS PRESS Ltd.

3. Volkov, V.E. (2014). Mathematical simulation of laminar-turbulent transition and the turbulence scale estimation. Odes 'kyi Politechnichnyi Universytet. Pratsi, 2, 155-159.

4. Volkov, V.E. (2014). Deflagration-to-detonation transition and the detonation induction distance estimation. Odes 'kyi Politechnichnyi Universytet. Pratsi, 1, 120-126.

5. Gotsulenko, V.V. (2007). On the problem of control of relaxation oscillations of a "singing" flame. Journal of Engineering Physics and Thermophysics, 80(3), 563-569.

6. Gotsulenko, V.V. (2008). Distinctive features of the intrachamber instability of combustion in liquidpropellant rocket engines. Journal of Engineering Physics and Thermophysics, 81(5), 935 - 940.

7. Liberman, M.A. (2008). Introduction to Physics and Chemistry of Combustion. Berlin, Heidelberg: Springer-Verlag.

\section{АНОТАЦІЯ / АННОТАЦИЯ / ABSTRACT}

В.Е. Волков. Одновимірна нестійкість полум'я та керування горінням в топці. Досліджено стійкість полум'я в замкненій камері згоряння, а також полум'я, що розповсюджується в замкнених каналах або трубах, відносно одновимірних збурень експоненційного типу. Доведено, що можливими є як стійкість, так і нестійкість процесу горіння. При цьому гарантовано одновимірну нестійкість біля передньої стінки камери згоряння, звідки здійснюється подача палива. Таким чином, керування горінням в топці зводиться до підтримування полум'я на найбільш можливій відстані від переднього фронту топки з метою недопущення виникнення режиму вібраційного горіння або зменшення інтенсивності пульсацій, якщо їх неможливо уникнути.

Ключові слова: полум'я, горіння, вібраційне горіння, нестійкість, ламінарність, турбулентність, камера згоряння.

В.Э. Волков. Одномерная неустойчивость пламени и управление горением в топке. Исследована устойчивость пламени в закрытой камере сгорания, а также пламени, распространяющегося в закрытых каналах или трубах, по отношению к одномерным возмущениям экспоненциального типа. Доказано, что возможны как устойчивость, так и неустойчивость процесса горения. При этом одномерная неустойчивость гарантирована у передней стенки камеры сгорания, откуда производится подача топлива. Таким образом, управление горением в топке сводится к поддержанию пламени на максимально возможном расстоянии от переднего фронта топки с целью недопущения возникновения режима вибрационного горения или уменьшения интенсивности пульсаций, если они неизбежны.

Ключевые слова: пламя, горение, вибрационное горение, неустойчивость, ламинарность, турбулентность, камера сгорания.

V.E. Volkov. One-dimensional flame instability and control of burning in fire-chamber. The flame stability with regard to one-dimensional exponential perturbations both for the combustion in the fire-chamber and the flame propagating in closed tubes or chambers is investigated. It is proved that both stability and instability are possible for the combustion process. At the same time the one-dimensional flame instability is guaranteed near the front wall of the fire-chamber where the fuel supply is realized. Therefore the control of combustion in the fire-chamber leads to support of the flame at the maximum possible distance from the front wall of the fire-chamber to prevent the vibratory combustion or to diminish intensity of pulsations if these pulsations are inevitable.

Keywords: flame, combustion, vibratory combustion, instability, laminarity, turbulence, fire-chamber. 